RESEARCH ARTICLE

\title{
Keys for the identification of common bees of Sri Lanka
}

\author{
W. A. Inoka P. Karunaratne and Jayanthi P. Edirisinghe \\ Department of Zoology, Faculty of Science, University of Peradeniya, Peradeniya
}

Revised: 01 March 2007 ; Accepted: 15 February 2008

\begin{abstract}
Illustrated keys are provided for the identification of 41 species of bees in 25 genera and three families that are commonly encountered on flowers of common flowering plants of Sri Lanka. The generic and species keys to bees are annotated with known natural history information on distribution, floral hosts, special behaviour at flowers, nest type and nesting sites. Details of external morphology of bees used in the keys have been included. A brief taxonomic history of bees relevant to Sri Lanka is also included.
\end{abstract}

Keywords: Common bees, floral hosts, identification-keys $\backslash$, taxonomic features, Sri Lanka

\section{INTRODUCTION}

There has been a long felt need for a key for the identification of bees of Sri Lanka that are commonly encountered on flowers of a variety of plants including cultivated plants of horticultural and agricultural importance, weeds and the natural vegetation. Previous studies on bees have tended to deal with the four wellknown species of hive -nesting honeybees of the family Apidae. The domesticated Asian honeybee, Apis cerana, the feral giant honeybee, Apis dorsata, the feral dwarf honeybee Apis florea and the stingless bee, Trigona iridipennis are common in rural and urban landscapes. Detailed information on non-honeybees or the solitary pollen bees of Sri Lanka that outnumber the honeybees was lacking until a recent field study ${ }^{1}$ on bees by the authors that covered most areas of the country.

This study has documented 138 species of bees in 35 genera collected from areas other than the North and North-East of Sri Lanka ${ }^{1}$. The keys developed in this study aid in the identification of the commonly occurring bees of Sri Lanka.

\section{A brief taxonomic history}

The earliest published work on bees of Sri Lanka dates back to the British Colonial Period when Bingham ${ }^{2}$ recorded, described and provided keys for 42 species of bees in 15 genera from Sri Lanka. Thereafter, the insect surveys conducted in Sri Lanka (1978-1998) by the Smithsonian Institution, Washington resulted in the identification of several bee species by Sakagami and Ebmer 3; Schwarz 4; Sakagami 5,6; Sakagami; Ebmer \& Tadauchi ${ }^{7,8}$; Snelling ${ }^{9}$ and Baker ${ }^{10}$. These publications are noteworthy in that they include descriptions and species keys for specific genera. The landmark publication on the bees of the world by Michener ${ }^{11}$ has included information and keys for several genera (27) of bees documented from Sri Lanka. An annotated list of bees of Sri Lanka listing 132 bee species in 25 genera and 4 families was published by Wijesekara ${ }^{12}$ through a survey of published literature on bees of Sri Lanka.

\section{Features used in the identification of bees}

Like all other insects bees have three body regions, head, thorax and abdomen (Figure 1). A description of the external morphological features used in the keys is given below.FiguresgiveninMichener,McGinleyandDanforth ${ }^{13}$ have been used for illustration of these features.

\section{Head}

The head bears a pair of antennae, two compound eyes, three simple eyes and three pairs of mouth parts formed into a proboscis or "tongue" (Figures $2 \mathrm{a} \& 2 \mathrm{~b}$ ). The difference in the number of antennal segments is useful in sex determination. The apical segments that form the flagellum of the antenna are 10 segmented in the female and 11 segmented in the male. The relative lengths of these segments, especially the basal segments, is of considerable value as a key character.

\footnotetext{
${ }^{*}$ Corresponding author
} 


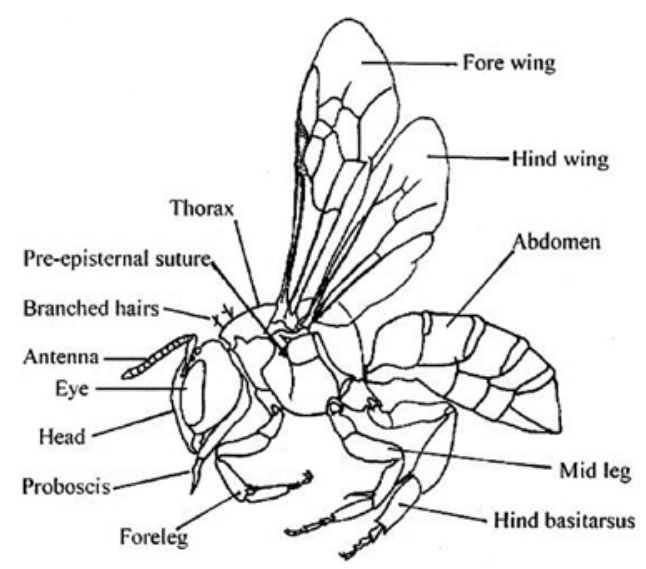

Figure 1: Body of a generalized bee
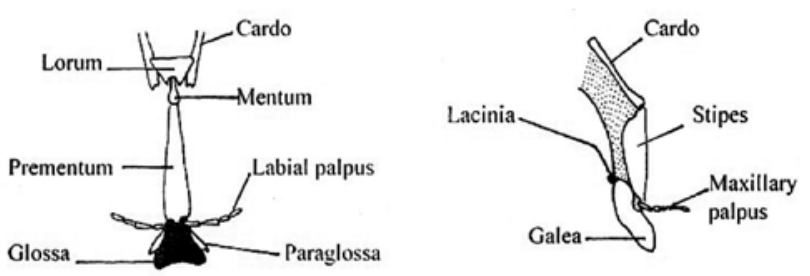

Figure 2b: Spread proboscis of a short-tongued bee

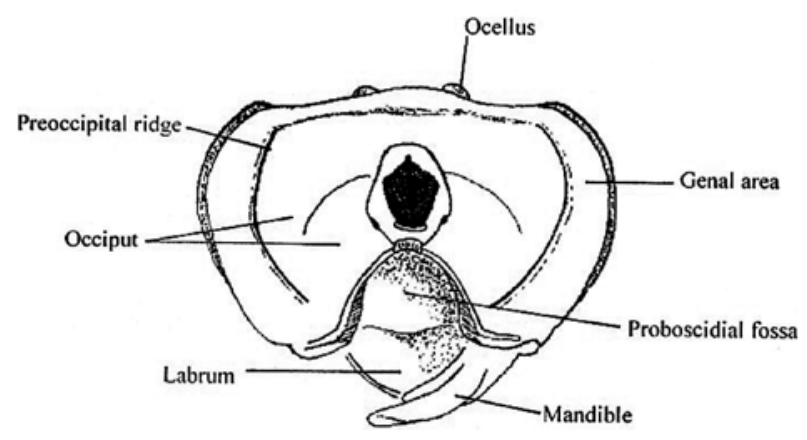

Figure 3b: Bee head - posterior view
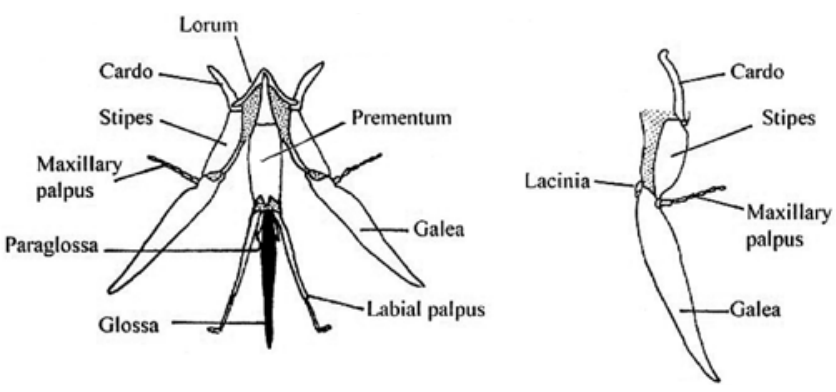

Figure 2a: Spread proboscis of a long-tongued bee

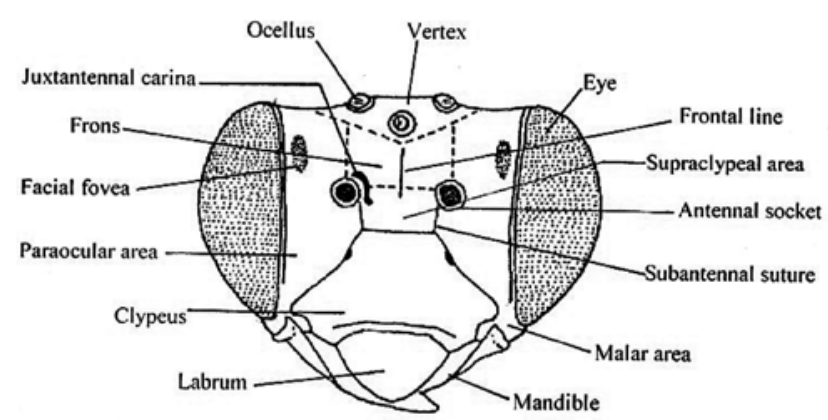

Figure 3a: Bee head - anterior view

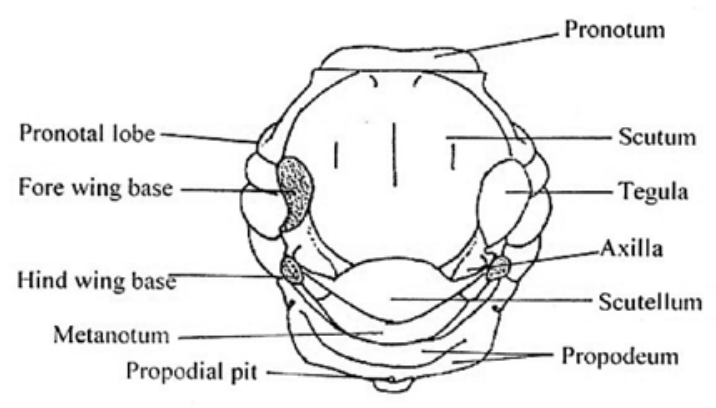

Figure 4a: Bee thorax - dorsal view

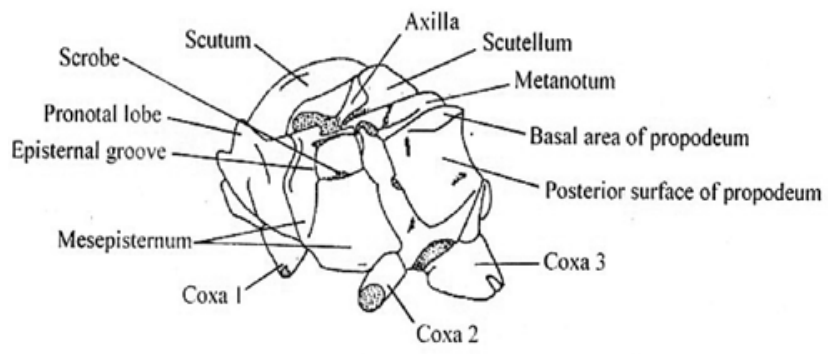

Figure 4b: Bee thorax - lateral view 
A large number of characters used in the higher classification of bees are based on features of the proboscis. The proboscis is formed of the maxillae and the labium. Each maxilla consists of the cardo, stipes, maxillary palp and galea. The labium consists of the prementum, glossa, paraglossa and the labial palps (Figures $2 \mathrm{a} \& 2 \mathrm{~b}$ ). In structurally more specialized bees, the glossa becomes acute and more or less elongated, the lacinia becomes reduced in size, the number of segments in the maxillary palps is reduced and various other modifications may be found. The proboscis is extended to probe flowers for nectar. Bees are grouped into either short-tongued or long-tongued species based on the modifications in the galea, labial palps and glossa. The labrum (upper lip) and mandibles are relatively simple generalized structures, not markedly different from most insects. However, they show a wide range in form and in relative size in different taxa.

The face is often divided into ill-defined areas, as indicated by dotted lines in Figure 3a. They are the two paraocular areas, the supra clypeal area, the frons or supra antennal area and the vertex. The malar area is between the eye and the mandible. The foveae of the face are depressions, usually black in colour.

The antennae arise from the antennal sockets (alveoli). Nearly all bees have a subantennal suture extending from each antennal socket down to the episternal suture (some have two sub-antennal sutures, below each antenna defining a subantennal area). The epistomal suture defines the upper limits of the clypeus. A longitudinal carina immediately mesal to the antennal base occurs in some bees, which is called the juxtantennal carina (Figure 3a). In some bees (e.g. Ceylalictus), the paraocular area seems to have moved downwards becoming lobed down into the clypeus on each side. The resultant lobe of the paraocular area into the clypeus is called the paraocular lobe. The term orbit is usually used for the eye margin, inner orbit for the facial margin and outer orbit for the genal margin. The genal area is the region behind the eye and in front of the preoccipital ridge. The ridge surrounding the concave posterior surface of the head above and laterally is called the pre-occipital ridge (Figure $3 b$ ). The proboscidial fossa (Figure 3b) is the large, deep groove on the underside of the head into which the proboscis folds.

\section{Thorax}

The thorax (Figures $4 \mathrm{a} \& 4 \mathrm{~b}$ ) of bees is a compact structure consisting of three segments; prothorax, mesothorax and the metathorax. The thorax bears legs and wings. The first true abdominal segment is termed the propodeum. The prothorax is represented primarily by the collar- like pronotum. The pronotum extends ventro-laterally forming the pronotal lobe (Figure 4b). In dorsal view, the mesothorax can be divided into four distinct sclerites; the scutum, scutellum and paired axillae. Laterally, the mesothorax is represented by the mesepisternum. This is sometimes divided by the nearly vertical episternal groove (pre-episternal groove). The episternal groove may extend down, often meeting the anterior end of the horizontal scrobal groove, on to the lower anterior part of the mesepisternum, as in the subfamilies Colletinae and Halictinae. Dorsally, the metathorax consists of the sclerite, metanotum. The metepisternum forms the lateral surface of the metathorax (Figure 4b).

The form and subdivisions of the propodeum are important systematically. The propodeum commonly exhibits 4 distinct surfaces; dorsal, posterior and lateral surfaces. In many species of groups these surfaces are defined by marginal carinae. The dorsal part of the propodeum is called the basal zone (basal area) and is further characterized by striations, reticulations or other sculpturing which are of considerable taxonomic importance. Many bees have a pair of impressed lines on the propodeum (dotted in Figure 4a), beginning near its anterior dorso-lateral parts and extending downward and postero-medially and nearly meeting in or above the propodial pit, a median depression of the lower posterior surface. These lines, together with the anterior dorsal margin of the propodeum, enclose the propodeal triangle.

\section{Wings}

The wings of bees exhibit a considerable range of variation between genera and the other higher taxa but are commonly of little help in the separation of species within a genus. Important differences in the forewing include the number of submarginal cells ( 2 or 3 ), the relative size of the stigma, the size and form of the marginal cell, the form of the basal vein and $2^{\text {nd }}$ recurrent vein, and the relations of the recurrent veins to the submarginal cells. Among the veins in the forewing, of special importance are the three veins that look like crossveins: the second abscissa of Rs (or first transverse cubital), first $\mathrm{r}-\mathrm{m}$ (or second transverse cubital), and second r-m (or third transverse cubital), named according to the Cumstock and Needham system. These veins help to define the sub marginal cells, which are usually either 3 or 2 in number. The veins are termed as $1^{\text {st }}, 2^{\text {nd }}$ and $3^{\text {rd }}$ submarginal crossveins (Figure 5a).

\section{Legs}

The three pairs of legs bear five segments; coxa, trochanter, femur, tibia and tarsus (Figure 6). The legs 


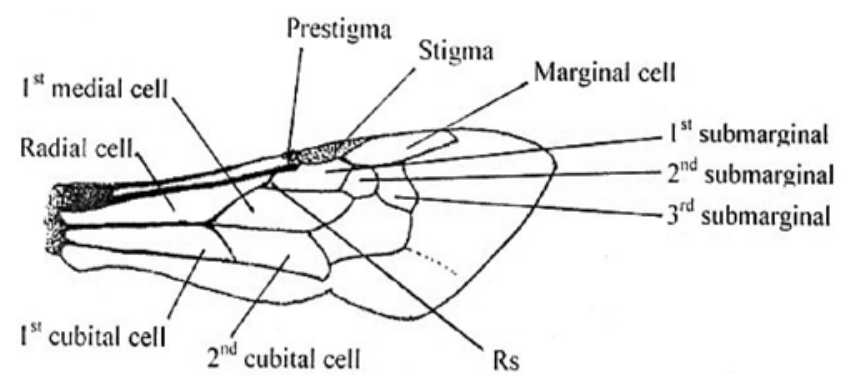

Figure 5a: Forewing with 3 submarginal cells

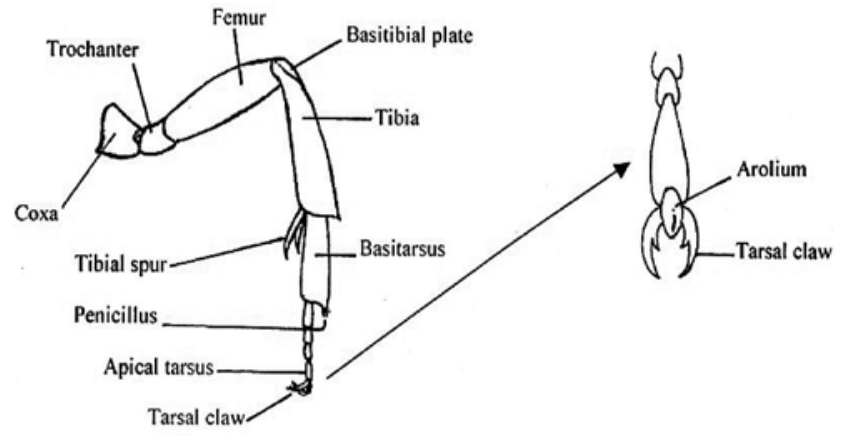

Figure 6: Hind leg of bee

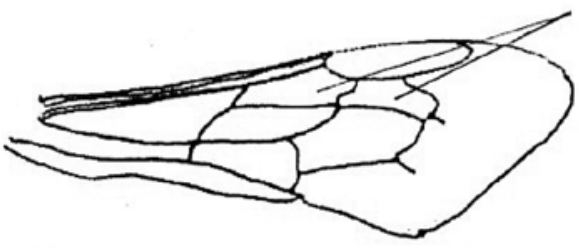

Figure 5b: Forewing with 2 submarginal cells

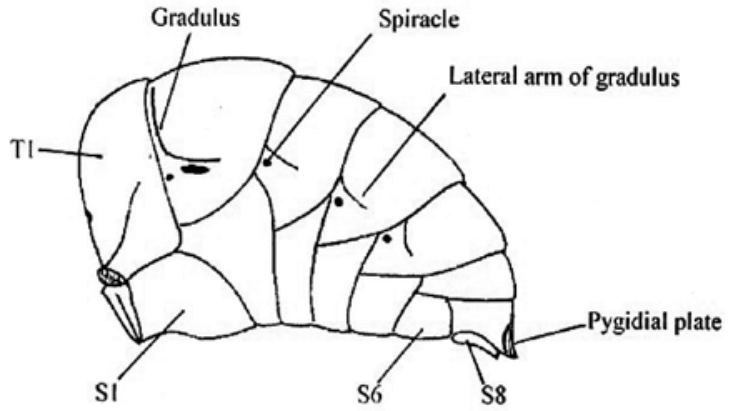

Figure 7a: Metasoma of male bee - lateral view

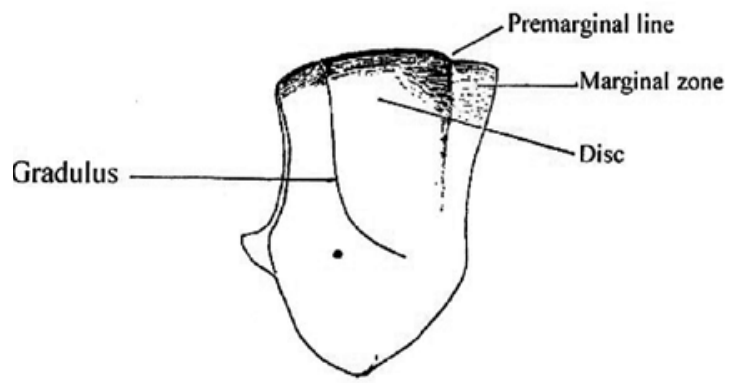

Figure 7b: Segment $\mathrm{T}_{3}$ - interal view

in most female bees differ from those of the other Hymenoptera chiefly in the broadening of the tibiae and basitarsi of the hindleg and to some degree, the basitarsi of the middle legs. Along with the expansion of these parts there has been a development of pollen collecting hairs, which are borne on hind legs in all groups except in the family Megachilidae. Because, male bees carry no pollen, these leg features are lacking, with all segments usually quite slender. In parasitic bees, both sexes are wasp-like in appearance, as the females also have lost their pollen carrying structures.

The tibial spurs are the movable inferior apical spurs on the tibiae; there is only one spur on the front tibia, one on the middle tibia and, in nearly all bees, two on the hind tibia. The inner hind tibial spur is especially important taxonomically. This spur usually has two toothed margins; the inner one that is commonly elaborated in various ways and an outer margin. The spurs are described as pectinate when its inner margin is produced into several long, coarse, often blunt projections, even though the number of such projections is in some cases reduced to only one or two. These spurs provide a hold against their nest burrow walls. Bees pivot on these spurs, somersaulting to change the direction of their head $^{14,15}$. The tibial spines (Figure 6) are immovable, sharp superior apical projections, usually small in size, often blunt or minute, found in some bees. There are none, 1 or 2 , or rarely 3 spines per tibia.

The basitibial plate is on the upper or outer side of the base of the hind tibia of many bees. It is best developed in females and presumably is important for support as bees move up or down with legs bent within their burrows in the 
soil $^{16}$. On the inner surface of the hind tibia of most bees is an area of variable size, covered with hairs of uniform length, usually blunt, truncate, or briefly bifid (Figure 6). These hairs, the keirotrichia, appear to serve for cleaning the wing. In some bees they are replaced by longer, more ordinary hairs that may function as part of the scopa in females. On the hind basitarsus of many female bees is a process that extends beyond the base of the second tarsal segment. Sometimes this process bears on its apex a small brush, the penicillus. Between the tarsal claws there is often a protruding pad-like arolium (Figure 6).

\section{Scopa}

Two forms of pollen collecting organs are found in bees. In all of the pollen bees (except in parasitic bees) they are composed of localized brushes of hairs, and the resulting organ is known as the scopa. Usually these scopal hairs are more elongate and spine-like than the other body hairs, and they may be either simple and unbranched or more or less densely plumose.

The honeybees of the family Apidae have a more specialized structure, called the corbicula or "pollen basket". In such bees the outer surface of the hind tibia is bare and highly polished and is surrounded by a marginal fringe of hairs, forming the basket. Female bees have scopae for holding and transporting pollen while the males lack such structures. Exceptions are the bees of Hylaeniae, Euryglossinae and Colletidae, parasitic and robber bees in various families, and queens of highly eusocial bees (Apidae), all of which lack scopae. The scopa consists of pollen carrying hairs in which pollen is carried back to the nest. In most bees the scopal hairs are on the hind legs, but in non-parasitic Megachilidae they are on the metasomal sterna; in some Collectids and Halictids they are on both the underside of the metasoma and on the hind legs.

\section{Metasoma}

Excluding the propodeum, which is the $1^{\text {st }}$ abdominal segment, the abdomen includes 6 well-defined segments in the female and 7 in the male. Each segment is composed of a dorsal, strongly arched tergum and a relatively flat ventral sternum. There are no pleural plates.

Metasomal terga and sterna are referred to as $\mathrm{T} 1$, $\mathrm{T} 2$, etc., and $\mathrm{S} 1, \mathrm{~S} 2$, etc. T1 and $\mathrm{S} 1$ constitute the basal segments of the metasoma (Figure 7a). Each metasomal tergum or sternum consists of a plate commonly marked by some transverse lines. Across the anterior margin, always completely hidden in the intact metasoma, is the antecostal suture. Near the posterior margin of each tergum and sternum is usually another transverse line, the premarginal line, separating the marginal zone from the rest of the sclerite (Figure 7b). T1 differs from other terga because its base is constricted to the narrow connection with the thorax. The terga are always provided with transverse bands of pale hair which are termed as metasomal bands.

The pygidial plate (Figure 7a) is usually a flat plate, commonly surrounded laterally and posteriorly by a carina and in some cases produced as an apical projection, on T6 in females and T7 in males. It is more often absent or rudimentary in males than in females. Soil dwelling females use the pygidial plate to compact the soil of burrows and cells ${ }^{17}$. Dense hairs on T6 of females, on each side of the pygidial plate, constitute the pygidial fimbriae, which are divided into two parts by the plate. $\mathrm{T} 7$ of the female is always completely hidden.

\section{Collection of bees}

Bees are active when the sun is out and can be collected from flowers, off vegetation and their nesting sites. A standard insect net can be used for collecting bees that is swung rapidly over vegetation. A net with a long-handle is used for collecting bees from tall trees. Bee specimens collected should be curated according to standard methods before identification.

\section{Material used in the key}

All materials upon which these keys are based were field collected and the specimens were either identified by experts (Dr. Alain Pauly, Dr. M. Terzo, Dr. S.W.T. Batra and Dr. B.B. Norden) or by the authors using taxonomic keys and descriptions and crosschecked with expert identified reference specimens lodged in the National Museum, Colombo and the Invertebrate Systematics and Diversity Facility (ISDF) of the University of Peradeniya.

\section{Identification keys}

The keys have been designed for use with bee specimens mounted on pins viewed under a stereo-microscope (magnification 2 x 0.7 - 4.5). Notes on general appearance, distinguished features, habits in life (buzzing at flowers and nectar robbing) and host-plant range as well as their distribution have also been included. This information can be an additional aid to identification. The keys provide salient features of 41 commonly occurring species of bees in 25 genera, and the 3 families (Halictidae, Megachilidae and Apidae). 


\section{KEY TO THE THREE COMMON FAMILIES OF BEES}

(modified from Insects of Australia, Superfamily Apoidea by C.D. Michener ${ }^{18}$ )

1. Mouthparts with the first 2 segments of the labial palp elongate, sheath-like, and flattened, in strong contrast to the distal 2 segments; galea with post palpal part generally elongate and usually longer than stipes; glossa elongate and pointed and usually longer than prementum (Long-tongued bees) (Figure 2a).

- Labial palp with the proximal and distal segments similar and sub-cylindrical; galea with post palpal part much shorter than stipes; glossa shorter than prementum (Short-tongued bees). Glossa pointed apically (Figure 2b); fore wing with 3 sub-marginal cells (Figure 5a); scopa on hind legs and base of the gaster.

HALICTIDAE (Page 78)

2. Fore wing with 2 sub-marginal cells (Figure 5b); scopa (pollen carrying hairs) when present is on the ventral side of the abdomen.

MEGACHILIDAE (Page 83)

Fore wing with 3 sub-marginal cells (only 1 cell in Trigona; only 2 cells in Braunsapis); pollen carrying structures when present is on the hind tibia either forming a scopa or a corbicula ( pollen basket).

.APIDAE (Page 74)

\section{KEY TO COMMON GENERA AND SPECIES OF FAMILY APIDAE}

1. Pollen carrying hairs in hind tibia of females forming a corbicula (pollen basket) (except in the queen bee); hind tibial spurs absent.

.7

- Pollen carrying hairs on hind tibia of females when present not forming a pollen basket; hind tibial spurs present (Figure 6).

2. Fore wing with 2 submarginal cells; slender bees with soft cuticle; most species are black with ivory or yellow marks on the face (triangular shape spot on female clypeus and square shape spot on male clypeus), often on the pronotal lobes and tarsi; fairly common genus visiting flowers of mostly herbaceous plants as well as trees; distributed in a wide range of altitudes in the Intermediate, Wet and Dry Zones of the country; nest in pithy stems as well as in preexisting holes in wooden structures.

Braunsapis

- Fore wing with 3 submarginal cells; combination of other characters different.

.3

3. Scopa absent in female; moderate sized bees; scutellum flat and produced posteriorly (Figure 8) as a sharply margined plate over metanotum, bidentate with broad V- or U-shaped emargination between teeth; body with areas of scale-like plumose hairs forming white, blue or blue-green spots or broken bands on abdominal terga; cleptoparasitic bees; 
wings largely bare and apically papillate (Figure 9); common in the Dry zone and favour dry weather conditions; visit flowers largely for nectar, scout around nests of bees.

..Thyreus

- Scopa present in female 4

4. Small and narrow bees, body less than $7 \mathrm{~mm}$ in length; integument shiny and nearly hairless or with short sparse hairs; pygidial plate absent in female; apex of T6 of female pointed; body black, dark brown-red or metallic blue-green; clypeus is an inverted ' $T$ ' shape (Figure 10); all species have yellow markings at least on face; wings not papillate.

Ceratina......8

- Broader bees; body greater than $8 \mathrm{~mm}$ in length; integument shiny or opaque, more or less hairy; distal part of wings beyond veins being strongly papillate; pygidial plate present in female (Figure 7); clypeus normal; colouration variable.

.5

5. Paraglossa long, often reaching the distal end of the second segment of the labial palpus; clypeus distinctly produced forward; tibial scopa with sparsely set branched hairs; males with very long antennae; body brown or black-brown, without coloured hair patches or bands; wings largely bare, the distal parts beyond the veins being strongly papillate; fast flying bees, pollen collecting restricted to floral species with large pollen grains as in Convolvulaceae (Argyreia populifolia, Ipomoea mauritiana) and Malvaceae (Hibiscus furcatus) flowers; rare bees, emergence of adults synchronize with the blooming of their host plants; nests in the ground.

Tetralonia

- Paraglossa normal; clypeus slightly produced forward; tibial scopa with closely set hairs; males have moderately long antennae; body mostly with coloured hair patches or bands.

. .6

6. Labrum much forwardly projected, prominent (Figure 11a); bees have metallic blue-green, yellow, orange or white metasomal bands except in one species; tibial scopa includes a band of plumose hairs near the upper margin of the tibia; moderate sized bees; fast flyers; common on nectar producing tubular flowers; buzz at Solanaceae flowers (e.g. brinjal); nest in the ground.

Amegilla .....9

- Labrum only slightly exerted (Figure 11b); not so prominent; parts of proboscis strongly sclerotized; abdomen without hair bands, but sometimes with pale hair cover; moderate to large sized bees; distal parts of the wings strongly papillate.

Xylocopa (carpenter bees).....11

7. Medium to large sized ( $8-16 \mathrm{~mm}$ in length) moderately hairy bees; body rather elongate; claws of females cleft (Figure 12); arolia present; wings with complete strong venation.

Apis.

- Small ( $<5 \mathrm{~mm}$ in length) bees; claws simple; hind basitarsus slender at base (Figure 13); sting absent; wings with marginal cells open at apex; one complete submarginal cell present (Figure 14); wings hyaline and brilliantly iridescent; very common in all parts of the country, visit a wide range of floral hosts for nectar and pollen; collect pollen even 
from freshly fallen flowers; social bee that nests in crevices of rocks, bark of trees and even in manmade structures.

Trigona iridipennis (stingless bee)

8. Body black to dark brown with yellow markings on almost all segments of the body; a very common bee that visits a wide range of flowering plants, mostly herbs; distributed throughout the country; nests in pithy stems of Gliricidia and rose.

Ceratina hieroglyphica

- Body brilliant metallic blue or green (females are greenish, males are bluish); yellow coloured markings are restricted to face and legs; a fairly common bee visiting mostly herbaceous plants in almost all parts of the country; nests in pithy stems of Gliricidia.

Ceratina binghami

9. Body entirely black covered with black to dark brown hairs; wings dark fuscous with a rich purple effulgence; pygidial plate rounded posteriorly; scopa entirely black with long plumose shining hairs; abdomen smooth and aciculate; largely found in the Dry Zone of Sri Lanka; prefers tubular flowers to collect nectar.

Amegilla violacea

- Head and thorax dark brown, abdomen black; T1 to T4 with an apical fascia of blue scales; wings subhyaline; pygidial plate tapering posteriorly; scopa white or with black and white plumose hairs.

10. T1 to T4 with an apical fascia of light metallic blue scale like hairs; scopa largely of white hairs; wings subhyaline, veins fuscous, tegula testaceous; found below $900 \mathrm{~m}$ in the three major agroecological regions of the country; prefer tubular flowers to collect nectar.

Amegilla puttalama

- T1 to T4 with an apical fascia of deep metallic blue scale like hairs; anterior half of the pollen brush with grayish-white hairs with a black-brown line ending at the middle of the tibia below the basitibial plate; wings subhyaline, veins fuscous, tegula testaceous; found below $900 \mathrm{~m}$ in the three major agroecological regions of the country; prefer tubular flowers to collect nectar.

Amegilla comberi

11. Thorax above of female with a thick coat of bright yellow hairs except for middle vertical line; thorax above of male with a thick coat of olive green hairs; basitibial plate tapers towards the middle of the tibia and ends bluntly (Figure 15); abdomen with black hairs laterally; legs black with black hairs; scutellum with a sharp transverse truncation overhanging the metanotum; wings fuscous with a purple effulgence; found largely in the Dry Zone of the country; mainly found on flowers of Leguminosae; buzz at flowers of Solanaceae crops to collect pollen.

Xylocopa ruficornis

- Thorax in the middle without hairs, shiny and surrounded by black-brown hairs; combination of other characters different. 
12. Wings dark fuscous with purple at base, turning to metallic blue followed by metallic green at the apex; basitibial plate tapers posteriorly forming an apical tooth that projects out (Figure 16); posterior margin of the scutellum lamellate and hangs over post-scutellum; abdominal segments fringed with long black hairs laterally; fairly common bee throughout the country; largely visits flowers of Leguminosae; buzz at flowers of Solanaceae and Melastomataceae to collect pollen; nest in rafters of old buildings.

Xylocopa tenuiscapa

- Wings entirely fuscous with a purple luster; combination of other characters different.

13. Less than $18 \mathrm{~mm}$ in length; basitibial plate with a row of tubercles on each side (Figure 17); black bee, thorax laterally covered with black-brown hairs; fairly common on flowers of Leguminosae such as Cassia and Crotalaria; found throughout the country.

Xylocopa fenestrata

- Length < $15 \mathrm{~mm}$; basitibial plate with 2 rows of small lateral tubercles (dorsal row prominent) that ends slightly below the middle of the tibia with 2 apical perpendicular teeth (Figure 18); black bees, in males area below the antennae and the clypeus creamywhite; largely found in the Dry Zone visiting small flowers of wild plants like Hyptis, Tachytarpheta and Tephrosia.

Xylocopa amethystina

14. Body length of worker bee $15-16 \mathrm{~mm}$ (largest in size); abdominal segments T1-T2 honeyyellow, rest black; wings hyaline at base, fuscous in the middle and darker towards the anterior margin, veins and tegula fuscous; common throughout the country visiting a variety of flowers; found in large numbers in flowering tall trees; nest in hives that hang from branches of huge trees, rocks and buildings.

Apis dorsata (the giant honeybee)

- Body length of worker $12 \mathrm{~mm}$ (medium in size); base of T1 -T5 testaceous, rest fuscous black; legs fuscous; wings subhyaline and iridescent, nerve and tegula fuscous; very common on flowering vegetation throughout the country; builds hives in crevices of trees and in manmade structures; domesticated in agriculture for obtaining honey and crop pollination.

Apis cerana (the domesticated/common honeybee)

- Worker body length $8 \mathrm{~mm}$ (smallest in size); head and thorax black, basal 2 segments of the abdomen more or less red; wings hyaline and iridescent, nerves testaceous, tegula black; found throughout the country on flowering trees and herbaceous plants; build hives in small branches of small-medium sized trees.

Apis florae (the dwarf honeybee) 


\section{KEY TO COMMON GENERA AND SPECIES OF FAMILY HALICTIDAE}

1. Marginal cell of fore wing tapers much toward its apex, which is not rounded; when there are three submarginal cells, $3^{\text {rd }}$ is shorter than $1^{\text {st }}$ and less than twice as long as second submarginal cell (Figure 19).

- Marginal cell of fore wing does not taper much toward its apex, which is rounded; when three submarginal cells present, $3^{\text {rd }}$ usually as long as $1^{\text {st }}$, if shorter, then usually twice as long as second submarginal cell (Figure 20).

.5

2. Females without scopa; abdomen partly or wholly red, sometimes entirely black in males; wasp-like with only few hairs on the body; sculpturing very prominent, head \& thorax above coarsely pitted; dorsal surface of the propodeum marked by a few coarse, often irregular longitudinal rugae delimiting shining spaces; prefer dry climatic conditions; not easily found on flowers but scout around flowers; parasitic in nests of other Halictid bees.

Sphecodes

- Females with a scopa on hind legs and base of abdomen; combination of other characters different

.3

3. Fore wing with $3^{\text {rd }}$ and often $2^{\text {nd }}$ submarginal cross vein and second recurrent vein weaker than the nearby veins in female (Figures 21a \& 21b); small, unattractive black to dark brown bees.

Lasioglossum

- First, $2^{\text {nd }}$ and $3^{\text {rd }}$ submarginal cross veins equally strong.

.4

4. Body metallic green; male with yellow areas on clypeus, femur and tibia; abdominal segments with yellowish-white basal and apical hair bands; genal area broader than the eye seen from side of the head (Figure 22); face below antennae and genal area behind eyes sparsely covered with short plumose white pubescence; legs covered with ochraceous pubescence; commonly found on flowers of herbaceous plants below $900 \mathrm{~m}$ elevation in the three major zones of the country; nest in soft sandy soil in bare ground found commonly in agricultural lands.

Halictus lucidipennis

- Non metallic bees; glossa very short; antennae simple in males; outer surface of the hind tibia with two areas of differently arranged hairs (Figure 23); body fuscous; scutum produced anteriorly to form a carina emarginated in the middle (Figure 24); pronotum widely emarginated in the middle and laterally produced to form a strong lamella towards pronotal lobes; basal area of propodeum large, carinate posteriorly, vertical striae forms a network at base; distributed around Peradeniya and Knuckles, buzz largely at Melastomataceae and Solanaceae flowers to collect pollen.

Patellapis kaluterae

5 Tegula enlarged posteriorly and passes the scuto-scuteller suture (Figure 25). 
- Tegula not enlarged, does not pass the scuto-scuteller suture 7

6. Fore wing with three submarginal cells; outer margin of eyes with a preoccipital carina (Figure 26); basitibial plate of female margined by a carina only on posterior side; hind tibiae of males with enlarged apical lobe; hind femur with ventral flap-like white hairs (Figure 27); lamella on the pronotal lobe translucent and larger than that of any other Nomiinae; abdominal terga with premarginal line prominent and elevated mostly laterally; body black; two antero-lateral patches on T1, basal fascia on T2, a basal and an apical fascia on T3 and T4 with snow-white pubescence; paraocular area on head, thorax laterally and legs with snow-white pubescence; hairs above thorax ochraceous, hairs very short and densely covering pronotal lobes and postscutellum above; wings fulvous and dusky towards the apex; most anterior part of tegula black with the rest orange-red; fairly common on a wide variety of floral hosts, specially on herbs below 900 m elevation; nests in the ground.

Pseudapis oxybeloides

- Fore wing with two submarginal cells; outer margin of eyes without preoccipital carina; prothoracic lamella well developed and covered with a thick coat of very short plumose fulvous hairs; head and thorax black; T1 and T2 red and the rest black; head, thorax laterally and legs covered with golden-yellow hairs; wings dusky and becoming darker towards the apex; found on flowers of herbaceous plants of the family Fabaceae; distributed in dry areas such as Randenigala, Puttalam, Hambantota and Chilaw; nests in the ground.

Steganomus nodicornis

7. Marginal zones of terga with integumental bands of white, yellow, green or blue.

- Marginal zones of terga without integumental bands, but with bands of coloured hairs.

8. Metanotum with two broad, basely fused, lame- lliform projections often joined to each other (Figure 28); body black-dark brown; abdomen smooth, basal four abdominal segments with bright green transverse fascia on apical margins; sides of T1 and T2 reddish brown; wings ochraceous, little dusky towards apex; face in front and body covered with plumose white hairs; legs with plumose white long hairs on outer surface and brownish yellow hairs on inner surface; common in a wide variety of flowering plants below $900 \mathrm{~m}$ elevation; ground nesting bees; Basitibial plate of female margined on both sides.

Hoplonomia westwoodi

- Metanotum without projections; basitibial plate of female margined by carina only on posterior side.

9

9. Outer hind tibial spur bent near at apex and with a subapical tooth (Figure 29); integumental bands of T1-T4 bright green; body black, face covered with grayish-white glittering plumose hairs; thorax above with black brown sparsely set short hairs; legs fuscous covered with fulvous hairs; visits a wide variety of floral hosts below $900 \mathrm{~m}$ elevation; ground nesting bee.

Curvinomia formosa

- Outer hind tibial spur without modified or bent apex, without subapical tooth; integumental bands white or yellow; combination of other characters not as above. 
10. Tergum 1 without a coloured band, with a pale hair band only laterally; hind femur of male without tooth; males with basitibial plate margined by carina on posterior side; marginal zones of T2-T4 with a white fascia; T5 with a fascia of long yellowish brown hairs; wings hyaline with a slight fulvous tint body black to dark brown; paraocular area covered with a thick coat of short glittering yellowish-white plumose hairs; scutum and scutellum above with a thick coat of very short brown hairs; post-scutellum densely covered with a thick coat of yellowish brown plumose hairs; legs fuscous with ochraceous pubescence; fairly common on a wide variety of floral hosts below $900 \mathrm{~m}$ elevation.

Leuconomia

- Tergum 1 with a coloured band; hind femur of male with tooth; male without basitibial plate; body black, apical margins of the abdominal segments 1-4 bright greenish yellow (not hairy), smooth and shiny; body covered with golden brown plumose hairs; thorax above covered with a thick coat of reddish brown plumose hairs; legs covered with golden fulvous hairs; found visiting a wide variety of herbaceous flowering plants below $900 \mathrm{~m}$ elevation.

Nomia crassipes

11. Pronotum with a continuous or medially notched transverse carina or lamella anterior to the scutum (Figure 30); basitibal plate of female delimited by a carina only along posterior side; metasoma with red areas in certain species.

Lipotriches....17

- Pronotum without a continuous carina or lamella; basitibial plate of female complete; glossa short; metasoma black.

Austronomia ....24

12. In females, fore wing with $2^{\text {nd }}$ and $3^{\text {rd }}$ submarginal cross veins and the $2^{\text {nd }}$ recurrent vein weaker than adjacent veins.

- Fore wing with only the $3^{\text {rd }}$ submarginal cross vein weaker and not the $2^{\text {nd }}$

13. Basal area of propodeum slightly carinate posteriorly head and thorax black; body length $5.5 \mathrm{~mm}$ distribution $>900 \mathrm{~m}$ elevation (confined to Nuwara Eliya, Sita Eliya, Badulla, Bandarawela, Knuckles); generalist bees visiting mostly herbaceous flowering plants; nests in the ground.

Lasioglossum (Evylaeus) carnifrons

- Basal area of propodeum not carinate posteriorly; Distribution $>900$ m elevation; body length $6.00 \mathrm{~mm}$ or more; combination of other characters not as above.

Lasioglossum (Sudila)

(Species key modified from Sakagami, Ebmer and Tadauchi, 1996) .14

14. Head and thorax black with metallic yellowish-green tint; abdomen black; propodeum broad and black with very fine diverging longitudinal striae; wings dusky towards the apical margin and iridescent; body covered with closely set plumose fulvous hairs; very common above $900 \mathrm{~m}$ elevation on a wide range of flowering plants; buzz at Melastomataceae and Solanaceae flowers to collect pollen; ground nesting bees.

Lasioglossum alphenum

- Head and thorax black without metallic green tint; combination other characters not as above. 
15. Mesoscutum and basal area of propodeum with fine and weak micro-reticulations thus appearing as homogenously granular and dimly shining; wings subhyaline and dusky towards apical margin; legs slender and fuscous; body covered with sparsely set ochraceous short hairs; found above $900 \mathrm{~m}$ elevation visiting a variety of flowering plants.

Lasioglossum bidentatum

- Mesoscutum and basal area of propodeum coarsely sculptured; basal area of propodeum large and the sculpturing is coarser; abdomen without hair bands; wings fulvous; legs fuscous; body relatively densely covered with long fulvous hairs than in other Sudila species; distributed above $900 \mathrm{~m}$ elevation and visits a wide variety of floral hosts for pollen.

Lasioglossum aulacophorum

16. Face elongated; glossa about as long as the head or even longer than the head; branching of the scopal hairs of the hind trochanter and femur reduced; abdomen basally red, fuscous apically; head and thorax black, $\mathrm{T} 1$ and $\mathrm{T} 2$ only at the basal half reddish-brown, rest fuscous; T2-T4 with a basal fascia of yellowish-white plumose hairs; wings hyaline; distributed around Peradeniya; collected largely on flowers of the family Convolvulaceae.

Lasioglossum (Nasohalictus) serenum

- Glossa very short, similar in length to the length of clypeus; face only slightly elongated; scopal hairs not as above; black bees; fairly common; distributed in the Wet, Intermediate and Dry Zones of Sri Lanka at $<900$ m elevation.

..Lasioglossum (Ctenonomia) amblypygus

17. In the male, antenna with 13 segments; scopa absent. 18 (Males ofLipotriches)

- In the female, antenna with 12 segments; scopa present on hind legs.

21 (Females of Lipotriches)

18. Ocelli surrounded by a carina; face below the antennae densely covered with a coat of short, plumose golden hairs; abdominal fascia thick and fulvous; tibia and basitarsi covered with a thick layer of long yellowish white plumose hairs on outer side

Lipotriches fulvinerva

- Ocelli without carina; combination of other characters not as above $\ldots 19$

19. S5 completely covered by long erected setae

- S5 without long erected setae; S4 with two small elliptical depressions perforated by pores; S5 without area of strong short setae; face below the antennae thickly covered with short, glittering ochraceous plumose hairs; legs slender.

Lipotriches exagens

20. S4 with a large depression completely filled by dense plumose white setae; $1^{\text {st }}$ abdominal segment petiolate; body black; face below the antennae with thick coat of whitish glittering plumose hairs; body hairs whitish.

Lipotriches pulchriventris

- $\quad$ S4 not depressed, glabrous; S5 with white pubescence; $1^{\text {st }}$ abdominal segment petiolate; face below the antennae with a thick coat of yellowish glittering plumose hairs; body hairs yellowish.

Lipotriches edirisinghei 
21. Ocelli surrounded by carina; metasoma black; pronotum with a very prominent medially notched transverse, translucent lamella anterior to the scutum at above the level of anterior scutal margin; basal area of propodeum very narrow, carinate anteriorly and posteriorly; head and thorax black; abdomen oval and fuscous-black; marginal zones broad and translucent covered with a broad fascia of thick coat of short yellowish white plumose hairs; T5 with long ochraceous hairs at the posterior half; wings fuscous; legs covered with glittering long ochraceous hairs; largely found on flowers of herbs and specially on grass flowers during early morning; prefers intermediate climatic zones.

Lipotriches fulvinerva

- Ocelli without carina; combination of other characters not as above. .22

22. Metasoma brown black; large species $(6-8.5 \mathrm{~mm})$ .23

- Metasoma partly red; smaller species (6 mm or less); pronotum carinate and always at the level of the anterior margin of the scutum, but not forming a lamella; head and thorax black; T1 and T2 reddish-brown, T3-T5 fuscous; marginal zones of T2 only laterally and a fascia on marginal zones of T3-T4 of yellowish white plumose hairs; legs fuscous; wings subhyaline and iridescent; commonly distributed in Kandy on a wide range of herbaceous flowering plants.

Lipotriches exagens

23. Clypeus and supraclypeal area at the same level; vertex carinate posteriorly; pronotum with a continuous short lamella anterior to the scutum and at slightly above the level of anterior scutal margin; head and thorax black, abdomen fuscous; marginal zones of T3, T4 and T1, T2 only laterally with a narrow fascia of short yellowish white plumose hairs; T5 with long fuscous hairs at its apical half; legs fuscous with long glittering hairs; collected only from Peradeniya on herbaceous flowers including grass flowers.

Lipotriches pulchriventria

- Suture between clypeus and supraclypeal area distinctly higher, raised above the surface forming a prominent horizontal ridge across the face between antennal base (Figure 31); pronotum with a medially notched transverse carina slightly raised above the anterior scutellar margin; body dark brown; T1-T3 at marginal zones light brown and translucent; marginal zones of T3,T4 and T1, T2 only laterally with short plumose yellowish-white hairs; legs fuscous; wings subhyaline; distributed in Peradeniya, Matale, Ratnapura, Kurunegala and Angunakolapelessa visiting a wide variety of flowering plants, specially grasses.

Lipotriches edirisinghei

24. Apical hair bands on T1-T4 are dense and of white hairs; T5 covered with long plumose white hairs; male femora and tibia slightly swollen; hind basitarsi slender, not swollen; head and thorax black; abdomen reddish-brown ventrally; wings fulvous and iridescent towards the apex; head in front below antennae densely covered with short glittering plumose hairs; scutum and scutellum above with very short ochraceous hairs; scutellum with hairs interspersed with sparsely set long fuscous hairs; post-scutellum above with long plumose white hairs; widely distributed in the three major zones of the country below 900 m elevation; visit a wide range of floral hosts specially herbaceous plants for pollen and nectar.

Austronomia notiomorpha

- T1 - T2 with a broad fascia of yellow plumose hairs; T5 with long plumose fuscous sparsely set hairs; male basitarsi distally swollen; hind femora and tibia slightly swollen; body black; face in front below the base of antennae with shinning short plumose yellowish hairs; scutum and scutellum above with short fulvous hairs; postscutellum 
densely covered with glittering yellowish grey hairs; distributed below $500 \mathrm{~m}$ elevation in the three major climatic zones of the country; visits a wide variety of floral hosts, specially herbaceous flowers for pollen and nectar.

Austronomia krombeini

\section{KEY TO COMMON GENERA AND SPECIES OF FAMILY MEGACHILIDAE}

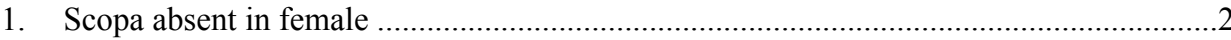

- Scopa present ventrally on abdomen in female ............................................................2

2. Interantennal area elevated with a strong curved juxtantennal carina mesal to each antennal base (Figure 32); black bee; head, thorax and abdomen evenly punctured; marginal zones shining and glabrous; two sharp juxtantennal carina starting from frons run down to join at the base of the antennae and meets a carina running upward from the clypeus, altogether forming a Y - shaped carina (Figure 32); abdomen with sparse punctures, marginal zones shining, glabrous; wings fuscous towards apex; prefer dry weather conditions; largely attracted to small tubular flowers like Hyptis suaveolens for nectar; cleptoparasitic on Megachile bees.

Euaspis edentata

- Juxtantennal carina absent; axillae on metanotum produced posteriorly to an angle or spine (Figure 33); apex of female abdomen elongated, pointed, apex of male abdomen with several long spines (Figure 34); eyes often hairy; body mostly black with patches of scaly white hairs on almost all segments of the body; prefer dry weather conditions; rare bees visiting flowers mostly for nectar; cleptoparasitic on carpenter bees.

Coelioxys

3. Less than $4 \mathrm{~mm}$ in length; thorax elongated; coarsely punctate; anterior face of $\mathrm{T} 1$ with large concavity surrounded by strong carina; body black, head in front specially the paraocular area, thorax laterally, legs, abdominal segments 1-5 apically covered with soft white pubescence; abdomen shiny and much convex dorsally, T6 tapering posteriorly; wings hyaline and iridescent; metasoma of male curled to expose only T1-T3 dorsally; common in flowers of herbaceous plants; nest in pre-existing holes in wood.

Heriades binghami

- More than $7 \mathrm{~mm}$ in length; combination of other characters different. .4

4. Mid facial prominence present in female (Figure 35) (slightly in male); outer surface of hind tibia with coarse tubercles (Figure 36) (strongly punctuate in male); body black, with white pubescence on paraocular area and apex of clypeus; abdominal segments 1-5 fringed with white pubescence; abdominal scopa black with sparsely set black hairs; wings slightly fuscous; specialist on large pollen grains of Convolvulaceae (Argyreia populifolia, Ipomoea cairica, I. mauritiana, I. pes-caprae) and Malvaceae (Hibiscus spp.) flowers.

Lithurgus atratus

- Facial prominence absent; outer surface of the hind tibia without coarse tubercles; dorsal side of the abdomen in most species with coloured hair bands sometimes covering the whole segment; scopa with closely set hairs; morphologically and behaviuorally diverse bees; females cut pieces of leaves to line nest cells; solitary bees that nest in stems.

Megachile ....5

5. Terga T1-T5 or at least $\mathrm{T} 1$ and/or T2 entirely covered with either orange, white or ochraceous hairs; T2-T5 with or without narrow fascia.

7 
- T1 or T2 not entirely covered with hairs; terga with narrow apical fascia of white or ochraceous hairs.

6. Middle and posterior femora orange red; pollen brush white; sides of face, pronotum and sides of thorax and narrow transverse fascia on apical margins of abdominal segments 1-5 with snow-white pubescence; found largely in the Dry Zone; prefers mostly flowers of herbaceous plants for pollen and nectar.

Megachile vigilans

- Legs black to dark brown; pollen brush orange brown; black bees with T1-T5 fringed with short plumose hairs; abdomen cordiform; wings hyaline and iridescent towards apex; largely found in the Dry Zone of the country; prefers herbaceous flowering plants for pollen and nectar; nests in bamboo stems and in hollows of stems.

Megachile hera

7. T2 - T5 without an apical fascia; T1 covered with white hairs .8

- $\quad$ T2 - T5 with a narrow fascia of white or ochraceous hairs .9

8. Scopa bright fulvous; thorax above with a smooth coat of brown-black hairs; wings fuscohyaline; body black; abdomen short, tapering posteriorly, above iridescent; Largely found in the Wet (Peradeniya) and Intermediate Zones of the country; mostly found on flowers of the family Fabaceae.

Megachile conjuncta

- Scopa black; thorax above with a coat of black hairs; wings hyaline at base, fuscous towards the apex with purple effulgence; body black, face in front, sides and ventral thorax and legs on outer side with black pubescence; propodeum posteriorly covered with thick long white - rusty-yellow pubescence; legs fuscous black; largely found in the Dry Zone on herbaceous flowering plants.

Megachile disjuncta

9. Wings fulvous; scopa yellowish white; T1 and T2 thickly covered with reddish-brown hairs; body black; face in front covered with a thick coat of fulvous pubescence; thorax above thickly covered with reddish-brown hairs; T1 and T2 thickly covered with reddishbrown hairs, remainder apically banded with white hairs; wings fulvo-hyaline, fuscescent along apical margin; common below $900 \mathrm{~m}$ elevation in all three major zones of the country; largely found on flowers of Fabaceae; solitary bees that nest in bamboo stems and in hollows of stems.

Megachile lanata

- Wings hyaline at base followed by an orange brown tint to end in dark fuscous at the apex; scopa white with the tip black; body black, face in front with fulvous black pubescence; on thorax laterally close to wing base, scutellum above sparsely and propodeum laterally with orange-brown hairs; T1 and T2 with a fascia of dark-brow orange hairs; fascia on T3 narrower and fulvous; T4 and T5 with a narrow white fascia; visits herbaceous flowers, common in all three major climatic zones of the country; nests in hollows of stems.

Megachile umbripennis 


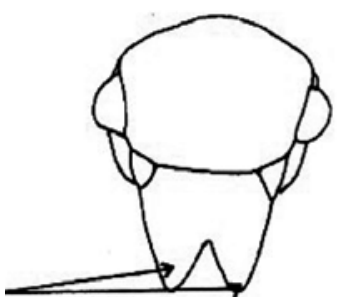

Figure 8: Posteriorly produced scutellum

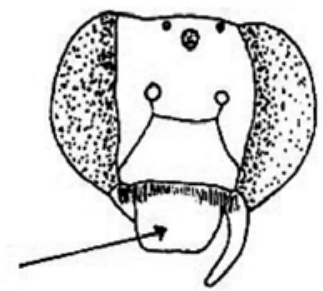

Figure 11a: Forwardly produced labrum on face

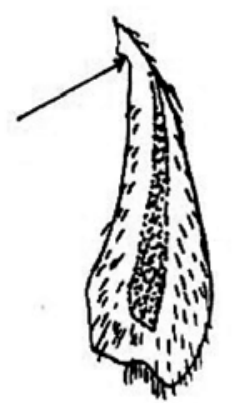

Figure 13: Slender base of basitarsus on hind leg



Figure 16: Apical tooth on basitibial plate on hind leg



Figure 9: Papillate apical half of forewing

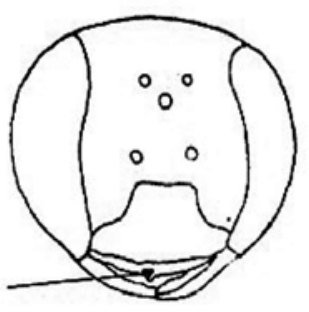

Figure 11b: Slighly protruding labrum on face

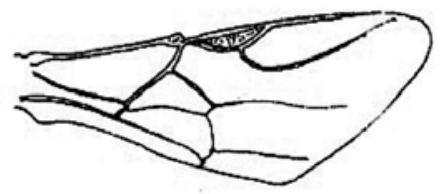

Figure 14: Single submarginal cell of forewing

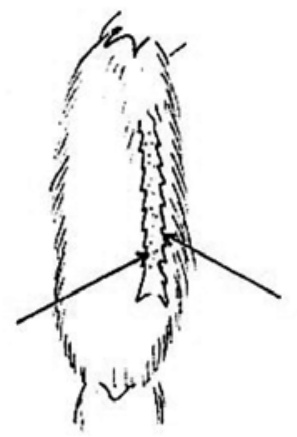

Figure 17: Basitibial plate with 2 rows of tubercles on each side

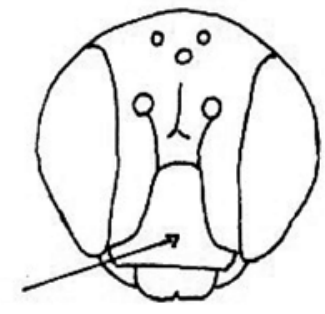

Figure 10: Inverted ' $\mathrm{T}$ ' shaped clypeus on face

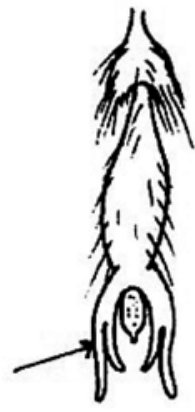

Figure 12: Cleft claw on hind leg

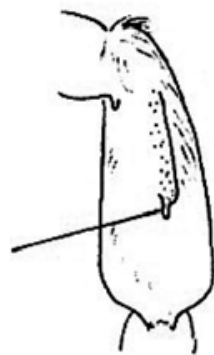

Figure 15: Bluntly ending basitibial plate on hind leg

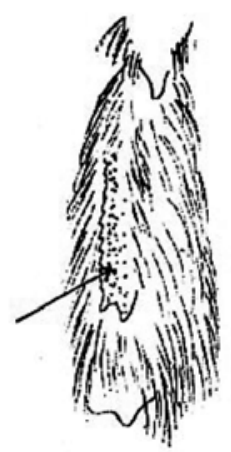

Figure 18: Basitibial plate with one row of tubercles prominent 


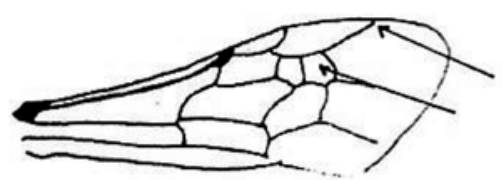

Figure 19: Forewing showing marginal and submarginal cells

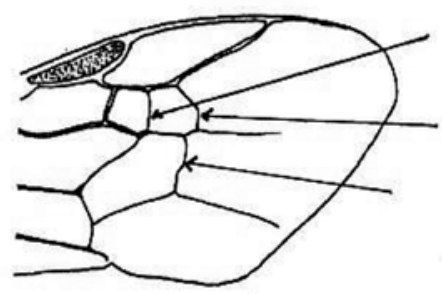

Figure 21b: Cross veins of forewing

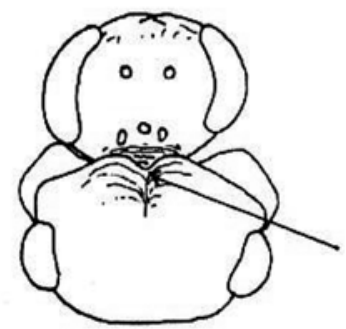

Figure 24: Medially emarginated carina on scutum

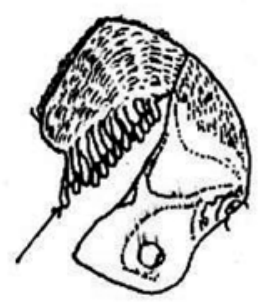

Figure 27: Flap-like white hairs on hind femur



Figure 20: Forewing showing marginal and submarginal cells

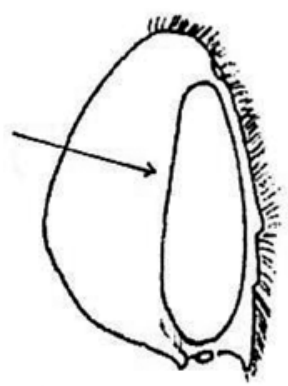

Figure 22: Broader genal area on face

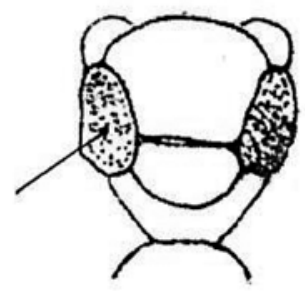

Figure 25: Enlarged tegula on thorax

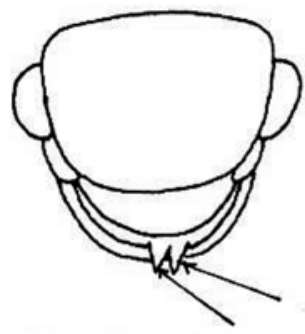

Figure 28: Two projecting teeth on scutellum

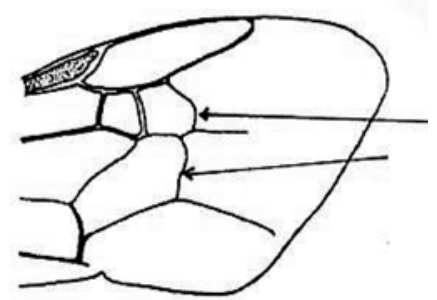

Figure 21a: Cross veins of forewing

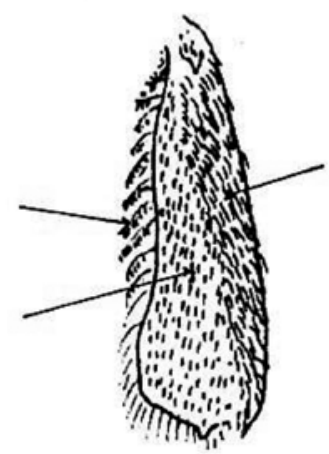

Figure 23: Differently arranged hairs on hind tibia

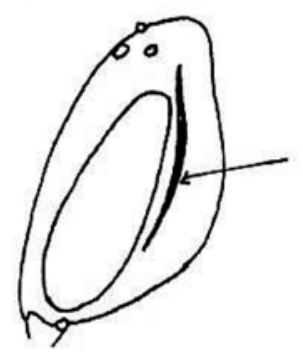

Figure 26: Carina behind eye

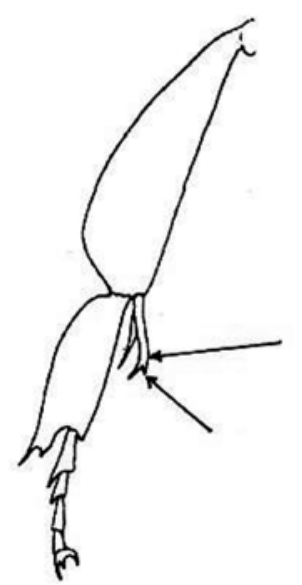

Figure 29: Apically bent hind tibial spur with sub-apical tooth 


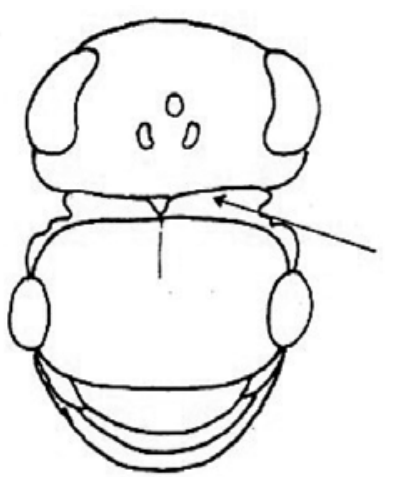

Figure 30: Pronotal carina medially notched

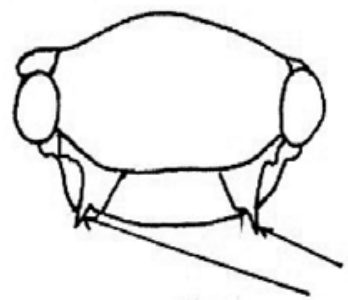

Figure 33: Protruding axillae on thorax

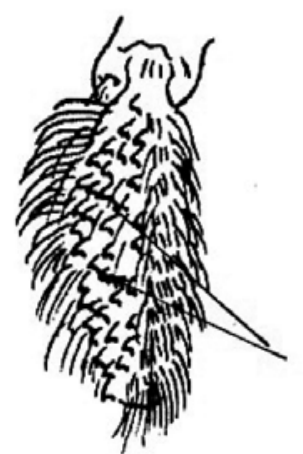

Figure 36: Hind tibia with coarse tubercles

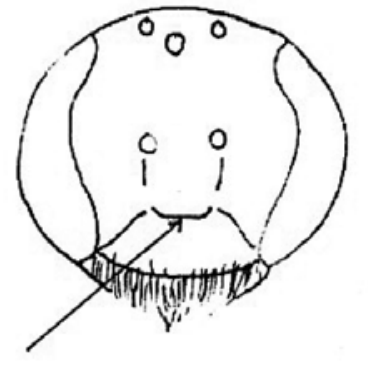

Figure 31: Horizontal ridge beleow antennal base

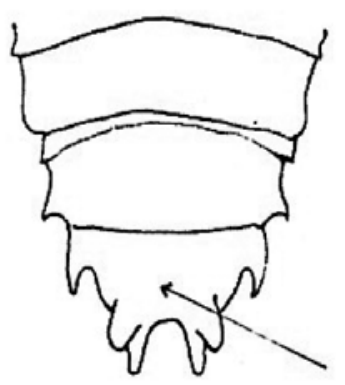

Figure 34: Tip of male abdomen with spines

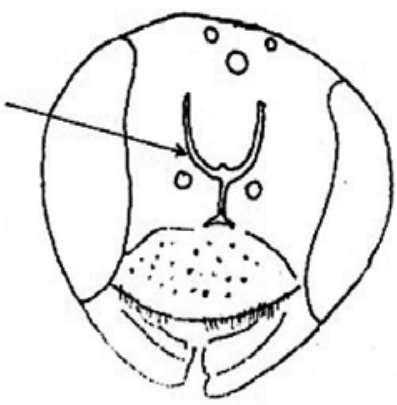

Figure 32: ' $\mathrm{Y}$ '- shaped carina on face

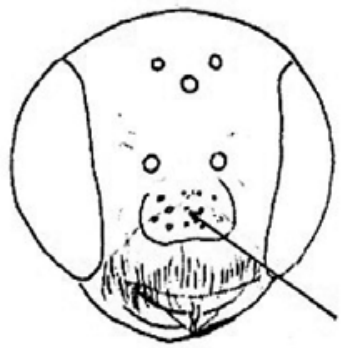

Figure 35: Mid facial prominence on face 
List of species covered by the key

\author{
Amegilla comberi Cockerell \\ Amegilla puttalama Strand \\ Amegilla violacea Lepeletier \\ Apis cerana Fabricius \\ Apis dorsata Fabricius \\ Apis florae Fabricius \\ Austronomia krombeini Hirashima \\ Austronomia notiomorpha Hirashima \\ Braunsapis Michener \\ Ceratina binghami Cockerell \\ Ceratina heiroglyphica Smith \\ Coelioxys Latreille \\ Curvinomia formosa (Smith) \\ Euaspis edentate Baker \\ Halictus lucidipennis Latreille \\ Heriades binghami Cameron \\ Hoplonomia westwoodi (Gribodo) \\ Lasioglossum alphenum (Cameron) \\ Lasioglossum amblypygus (Strand) \\ Lasioglossum aulacophorum (Strand) \\ Lasioglossum bidentatum (Cameron) \\ Lasioglossum carnifrons (Cameron) \\ Lasioglossum serenum (Cameron) \\ Leuconomia Pauly
}

\author{
Lipotriches exagens (Walker) \\ Lipotriches fulvinerva (Cameron) \\ Lipotriches pulchriventris (Cameron) \\ Lipotriches edirisinghei (Pauly) \\ Lithurgus atratus Smith \\ Megachile conjuncta Smith \\ Megachile disjuncta Fabricius \\ Megachile hera Bingham \\ Megachile lanata Fabricius \\ Megachile umbripennis Smith \\ Megachile vigilans Smith \\ Nomia crassipes Fabricius \\ Patellapis kaluterae (Cockerell) \\ Pseudapis oxybeloides (Smith) \\ Sphecodes Latreille \\ Steganomus nodicornis Smith \\ Tetralonia Spinola \\ Thyreus Panzer \\ Trigona iridipennis Smith \\ Xylocopa amethystine Fabricius \\ Xylocopa fenestrate (Fabricius) \\ Xylocopa tenuiscapa Westwood \\ Xylocopa ruficornis Fabricius
}

\section{Acknowledgement}

The authors gratefully acknowledge Drs. S.W.T. Batra (formerly of the USDA, Beltsville.), B.B. Norden (formerly of the Smithsonian Institution, Washington, USA) for initiating and encouraging bee research in Sri Lanka. Drs. Alain Pauly (Department Entomologie, Institut Royal des Sciences Naturelles de Belgique, RueVautier 29, Belgium) and M. Terzo (FRNS Scientific Researcher, University of Mons-Hainaut, Belgium) are gratefully acknowledged for identifying Nomiinae bees and Ceratina species respectively. The Director General, Department of Wildlife Conservation and the Conservator General of the Forest Department are acknowledged for granting permission to collect bees from field sites coming under their purview and for issuing permits to send specimens to abroad for identification. Field assistance provided by Mr. C.M.B.S. Chandrasekara and Mr. R.M.N. Ratnayake is gratefully appreciated. The study was funded by a research grant from the Natioanl Science Foundation of Sri Lanka awarded to the second author.

\section{References}

1. Karunaratne W.A.I.P. (2004). Taxonomy and natural history of bees in selected areas of Sri Lanka. Ph.D. Thesis, Faculty of Science, University of Peradeniya, Peradeniya.

2. Bingham C.T. (1897). The Fauna of British India including Ceylon and Burma, Hymenoptera Vol. 1, Wasps and Bees. Taylor and Francis. London.

3. Sakagami S.F. \& Ebmer P.A. (1987). Taxonomic notes on oriental halictine bees of the genus Halictus (Subgen. Seladonia) (Hymenoptera Apoidea), Linzer Biologische Beiträge 19(2): 301-357.

4. Michener C.D. (2000). Bees of the world. Baltimore, Maryland, USA.

5. Sakagami S.F. (1978) Tetragonula stingless bees of the Continental Asia and Sri Lanka (Hymenoptera, Apidae), Journal of the Faculty of Science, Hokkaido University, Series VI, Zoology 21(2): 165-247.

6. Sakagami S.F. (1991). The halictid bees of Sri Lanka and the vicinity II. Nesohalictus (Hymenoptera: Halictidae). Zoological Science Hokkaido University, Japan. 8: 169178.

7. Sakagami S.F., Ebmer A.W. \& Tadauchi O. (1996). The Halictine bees of Sri Lanka and the vicinity. III. Sudila (Hymenoptera: Halictidae) Part 1. Esakia 36: 143-189. 
8 Sakagami S.F., Ebmer A.W. \& Tadauchi O. (1998). The Halictine bees of Sri Lanka and the vicinity III. Sudila (Hymenoptera: Halictidae) Part 2. Esakia 38: 55-83.

9. Snelling R.R. (1980). New bees of the genus Hylaeus from Sri Lanka and India (Hymenoptera: Colletidae). Contributions in Science (Natural History Museum of Los Angeles County) 328: 1-18.

10. Baker D.B. (1996). Notes on some palearctic and oriental Systropha, with descriptions of new species and a key to the species (Hymenoptera: Apoidea: Halictidae), Journal of Natural History 30: 1527-1547.

11. Michener C.D. (2000). The Bees of the World, pp 913. Johns Hopkin University Press, Baltimore, Maryland, USA.

12. Wijesekara A. (2001). An annotated list of bees (Hymenoptera: Apodea: Apiformes) of Sri Lanka, Tijdschrift voor Entomologie 144: 145-158.
13. Michener C.D., McGinley R.J. \& Danforth B.N. (1994). The bee genera of North and Central America. Washington D.C.

14. Anzenberger G. (1977). Ethological study of African carpenter bees of the genus Xylocopa (Hymenoptera, Anthophoridae). Z. Tierpsychol. 44:337-374.

15. Batra S.W.T. (1984). Solitary bees. Scientific American 250 (2):120-127.

16. Batra S.W.T. (1964). Behaviour of the social bee Lasioglossum zephyrum within the nest. Insectes Sociaux 11,159-186.

17. Batra S.W.T. (1980). Ecology, behaviour, pheromones, parasites and management of the sympatric vernal bees, Colletes inaequalis, C. thoracicuc and C. validus. Journal of the Kansas Entomological Society 53: 461-466.

18. Michener C.D. (1970). Superfamily Apoidea. The Insects of Australia, A Textbook for Students and Research Work Melbourne University Press, Australia. 